EESTI NSV TEADUSTE AKADEEMIA TOIMETISED. V KOIDE BIOLOOGILINE SEERIA. 1956, NR. 3

ИЗВЕСТИЯ АКАДЕМИИ НАУК ЭСТОНСКОИ ССР. ТОМ V СЕРИЯ БИОЛОГИЧЕСКАЯ. 1956, 수 3

\title{
МЯСНЫЕ КАЧЕСТВА, РАЗВИТИЕ ТКАНЕИ И ОРГАНОВ У БЫЧКОВ И БЫЧКОВ-КАСТРАТОВ ЭСТОНСКОЙ КРАСНОЙ ПОРОДЫ ПРИ РАЗЛИЧНЫХ УСЛОВИЯХ КОРМЛЕНИЯ
}

\author{
П. Я. АРАНДИ, \\ доктор сельскохозяйственных наук
}

В связи с возрастающим спросом населения городов и промышленных центров Эстонии на высококачественную мясную продукцию в настоящее время весьма остро стоит вопрос о производстве так называемой гастрономической телятины и говядины. Учитывая важность рационального использования в колхозах и совхозах республики сверхремонтного молодняка в качестве дополнительного источника мяса, автор работы поставил перед собой задачу выяснить мясные качества эстонского красного скота. Эта порода в течение своего исторического развития разводилась в молочном направлении. В связи с этим вопрос о том, в какой степени удастся воздействовать на качество мяса молодняка и на его скороспелость путем применения различного уровня и типа кормления, представляет большой хозяйственный и научный интерес. Параллельно с определением эффективности выращивания на мясо сверхремонтного молодняка различного возраста мы стремились изучить также и развитие важных внутренних органов и тканей при различных условиях кормления. Әти сведения углубляют и расширяют наши знания в области выращивания молодняка и в обобщенном виде дают некоторые исходные положения для разработки научных основ целенаправленного кормления растущих животных эстонской красной породы.

\section{Материал и методика опытов}

Опыты по изучению мясных качеств, развитию тканей и основных внутренних органов велись на Тяхтвереской экспериментальной базе Института животноводства и ветеринарии Академии наук Эстонской ССР (опорный пункт «Ворбузе»). Под опытом находилось 5 групп бычков (группы I, II, III, IV и VI) *, всего в количестве 37 животных. По группам они распределялись следующим образом: I группа -10 , II -7 , III -8 , IV -5 и VI - 4 бычка. Дополнительно к этому были забиты 3 бычка хозяйственного выращивания (Тяхтвереской экспериментальной базы) и 2 бычка (в возрасте 12 месяцев) ниже средней упитанности, приобретенные нами для сравнения на Тартуском мясокомбинате. Таким образом, общее количество забитых животных составляло 42 головы.

* V группа состояла главным образом из телок. 
Всех животных, входящих в подопытные группы, кормили индивидуально, все съеденные корма точно учитывались, а их химический состав подвергался изучению.

Забои проводились в возрасте 2 дней, 3 (животные I группы), 6, 12 и 18 месяцев (в последнем возрасте животные I и II групп).

Бычки, предназначенные на забой после 6-месячного возраста, были кастрированы в возрасте 3-4 месяцев. Исходя из литературных данных, такой возраст кастрирования следует считать вполне приемлемым $\left({ }^{7}\right)$.

Контрольные забои животных производились на Тартуском мясокомбинате (после 24-часовой голодной выдержки). При этом определялись убойный выход, количество крови и вес внутренних органов. Для изучения соотношения и состава тканей в туше одну ее продольную половину (правую) подвергали обвалке. Тущи разрубались на две одинаковые части по позвоночному столбу (точно по позвоночному каналу) при помощи специальной электропилы. При такой технике разделки и высокой опытности работников максимальная разница в весе обеих половин не превышала 1 процента.

Для изучения морфологического и химического состава туш препарировались отдельно: а) мускульная ткань, б) жировая ткань, в) кости, г) сухожилия и фасции. Из мяса и жира брались средние пробы для химического анализа, на основе которого определялась калорийность мяса.

\section{Кормление и развитие подопытных бычков}

Выпоенное подопытным бычкам (до 6-месячного возраста) количество цельного и снятого молока составляло от 184 (IV группа) до 398 кг корм. ед. (II группа), а скормленное количество концентратов - от 88 (VI группа) до 214 кг корм. ед. (I группа). Грубые и сочные корма предоставлялись молодняку всех групп вволю. Как видно из данных таблицы 1 , на наиболее высоком уровне кормления выращивалась II группа бычков, получавших обильное молочное кормление. По сравнению с первыми двумя группами, бычки III и IV групп, воспитывавшиеся на более низком уровне кормления молоком, потребили грубых и сочных кормов несколько больше (на $7-21 \%$ ). Несмотря на это, общий уровень кормления животных этих групп, по сравнению с I и II группами, оказался на $11-37 \%$, а потребление сухого вещества корма - на 6-20\% меньшим.

Таким образом, молодняк изучаемой породы до 6-месячного возраста, получавший несколько меньше молока, не был в состоянии потребить эквивалентное количество питательных веществ за счет грубых и сочных кормов.

В период от 7 до 12 месяцев количество скормленных концентратов предопределяло уровень кормления. Бычки I, II и III групп, получавшие больше концентратов, потребили также больше грубых и сочных кормов (502 - 728 корм. ед.), чем бычки IV и VI групп (480 и 409 корм. ед.). В относительных же показателях IV и VI группы потребили грубых и сочных кормов больше (на $2-38 \%$ ), однако общий уровень кормления у них оказался на $25-98 \%$ ниже, чем VI, II и III групп.

Из приведенных цифр вытекает, что во второй половине первого года жизни молодняк эстонской красной породы еще нуждается в определенном количестве концентратов.

До 18-месячного возраста в этих опытах содержались только представители I и II группы. В первой половине второго года, как и в период от 7 до 12 месяцев, уровень кормления, а также потребленное количество сухого вещества определялись долей концентратов в рационах. 
Фактическое потребление бычками кормов и питательных веществ, кг

\begin{tabular}{|c|c|c|c|c|c|c|c|c|c|c|c|}
\hline Корма & Mo. & ооко & & & & & & & \% & & ix \\
\hline Группы & цельное & снятое & 훙 & 울임 & बृ. & ङ & ư & ड़ & लेँ : & 응몸푬 & 递文 \\
\hline
\end{tabular}

до 3 месяцев:

I $|403,1| 411,5|26,0|-|-|-|4,0|-|61,7| 239,70 \mid 34,324$

до 6 месяцев:

\begin{tabular}{r|c|c|c|c|c|c|r|r|r|r|r} 
I & 403,1 & 1147,8 & 199,2 & 140,8 & 20,0 & - & 134,3 & - & 383,6 & 675,41 & 108,860 \\
II & 600,3 & 1394,2 & 195,7 & 40,0 & - & - & 117,7 & - & 437,6 & 740,58 & 119,562 \\
III & 309,7 & 1104,5 & 183,8 & - & 65,8 & - & 46,2 & - & 791,7 & 611,31 & 82,511 \\
IV & 554,2 & - & 185,4 & 111,6 & - & - & 125,0 & - & 570,6 & 541,53 & 62,329 \\
VI & 496,8 & 1363,5 & 113,5 & 4,4 & - & - & 4,7 & - & 984,2 & $636,6 !$ & 89,193
\end{tabular}

до 12 месяцев:

\begin{tabular}{r|r|r|r|r|r|r|r|r|r|r|r} 
I & 403,1 & 1238,0 & 558,7 & 1628,6 & 793,8 & - & 851,2 & 8,7 & 408,3 & 1815,07 & 262,017 \\
II & 600,3 & 1513,4 & 724,4 & 1307,0 & 10,0 & - & 927,0 & 4,7 & 437,6 & 1848,67 & 310,390 \\
III & 309,7 & 1194,5 & 407,8 & 848,0 & 84,1 & - & 792,7 & - & 1136,4 & 1351,95 & 152,356 \\
IV & 554,2 & - & 279,7 & 1159,2 & 92,7 & 62,5 & 756,5 & - & 834,7 & 1115,43 & 117,287 \\
VI & 496,8 & 1366,0 & 300,8 & 721,6 & 11,0 & 122,3 & 638,8 & - & 1374,4 & 1227,59 & 147,251
\end{tabular}

до 18 месяцев:

\begin{tabular}{r|r|r|r|r|r|r|r|r|r|r|r} 
I & 403,1 & 1238,0 & 784,7 & 2088,6 & 1142,8 & - & 1269,3 & 8,7 & 3579,9 & 2843,77 & 395,020 \\
II & 600,3 & 1513,4 & 1274,6 & 1970,0 & 81,0 & - & 1261,6 & 4,7 & 2982,6 & 3041,80 & 503,356
\end{tabular}

В связи с различным кормлением подопытные животные отличались также различной интенсивностью роста и развития (табл. 2).

В возрасте 6 месяцев бычки всех групп, кроме IV, по живому весу превышали требования класса элита-рекорд. Большинство же бычков IV группы, которым давали меньше молока, были отнесены ко II-му классу.

таблица 2

Динамика живого веса и среднесуточных привесов

\begin{tabular}{|c|c|c|c|c|c|c|c|}
\hline \multirow[b]{2}{*}{ Группы } & \multicolumn{4}{|c|}{ Живой вес, кг } & \multicolumn{3}{|c|}{ Привес, r } \\
\hline & $\begin{array}{c}\text { При рож- } \\
\text { дении }\end{array}$ & 6 мес. & 12 мес. & 18 мec. & $6 \begin{array}{l}\text { До } \\
6 \text { мес. }\end{array}$ & $\begin{array}{l}6-12 \\
\text { мес. }\end{array}$ & $\begin{array}{c}12-18 \\
\text { мес. }\end{array}$ \\
\hline $\begin{array}{l}\text { I } \\
\text { II } \\
\text { III } \\
\text { IV } \\
\text { VI }\end{array}$ & $\begin{array}{l}36 \\
38 \\
36 \\
37 \\
36\end{array}$ & $\begin{array}{l}192,5 \\
205,4 \\
175,6 \\
159,3 \\
196,2\end{array}$ & $\begin{array}{l}320,8 \\
352,8 \\
293,0 \\
237,0 \\
280,0\end{array}$ & $\begin{array}{c}427,0 \\
459,5 \\
- \\
-\end{array}$ & $\begin{array}{l}857 \\
917 \\
765 \\
670 \\
878\end{array}$ & $\begin{array}{l}703 \\
805 \\
643 \\
426 \\
459\end{array}$ & $\begin{array}{l}582 \\
587 \\
- \\
- \\
-\end{array}$ \\
\hline
\end{tabular}

В годовалом возрасте живой вес бычков I и II групп отвечал требованиям класса элита-рекорд, III группы - класса элита, VI группы - первого класса, IV группы - второго класса. В возрасте 18 месяцев I и II 


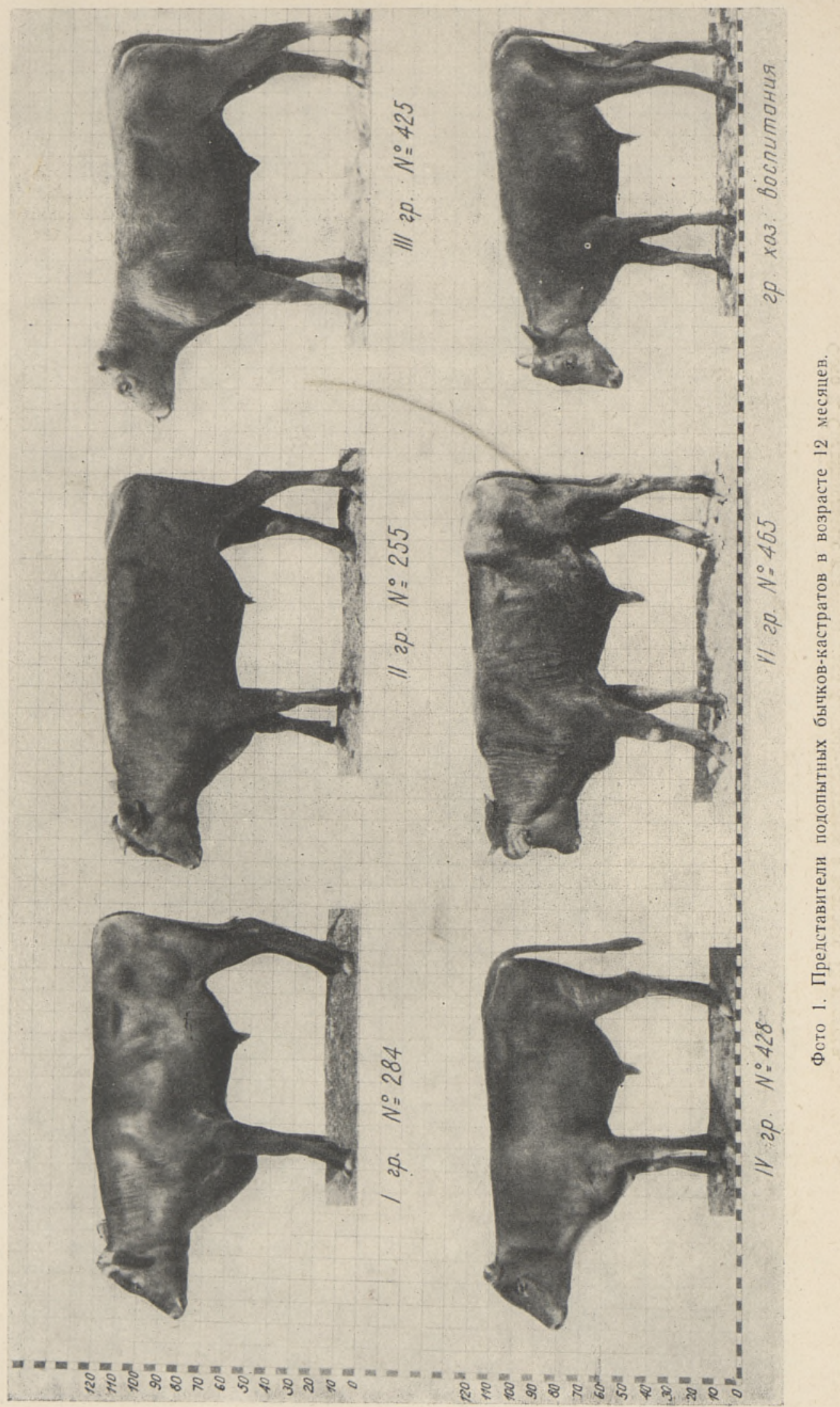




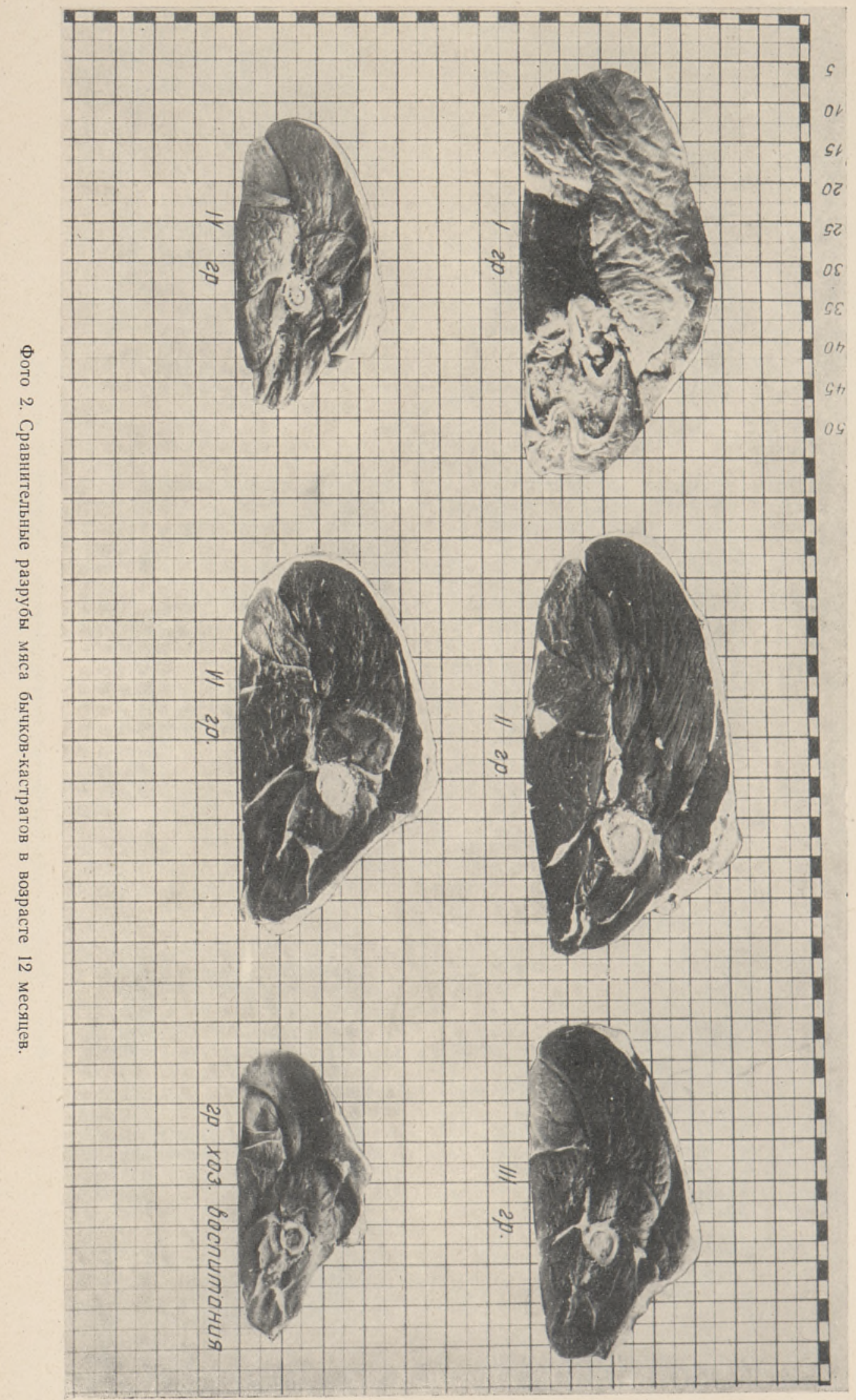


группы были отнесены к классу элита-рекорд. Значительная разница между группами отмечалась и в развитии телосложения. Так, бычки I и II групп в годовалом возрасте превышали животных IV группы по высоте в холке на 9 см, по обхвату груди на 56 см и т. д. и отличались также более компактным телосложением и измененным конституциональным типом, приближающимся к молочно-мясному направлению (фото 1).

В связи с различным кормлением и развитием сложились также различные мясные качества животных.

\section{Мясные качества бычков и бычков-кастратов}

Данные, приведенные в таблице 3 , говорят о том, что телята изучаемой породы уже в 3-месячном возрасте в условиях хорошего кормления отличаются довольно хорошими мясными качествами (убойный выход составляет около $53 \%$ ). Удельный вес внутреннего сала в этом возрасте является еще сравнительно незначительным. К 6-месячному возрасту выход мяса и сала у большинства групп повысился на $2-8 \%$. При этом обращает на себя внимание тот факт, что внутреннее сало образовывается главным образом после 3-месячного возраста. Так, в тушках новорожденных телят (забитых в целях выяснения исходного состояния тканей) внутренний жир практически отсутствовал. Его количество к 3-месячному возрасту увеличилось до $1,5 \mathrm{kr}$, а к 6-месячному возрасту - до 4-6 кг.

таблица 3

Убойные выходы бычков и бычков-кастратов

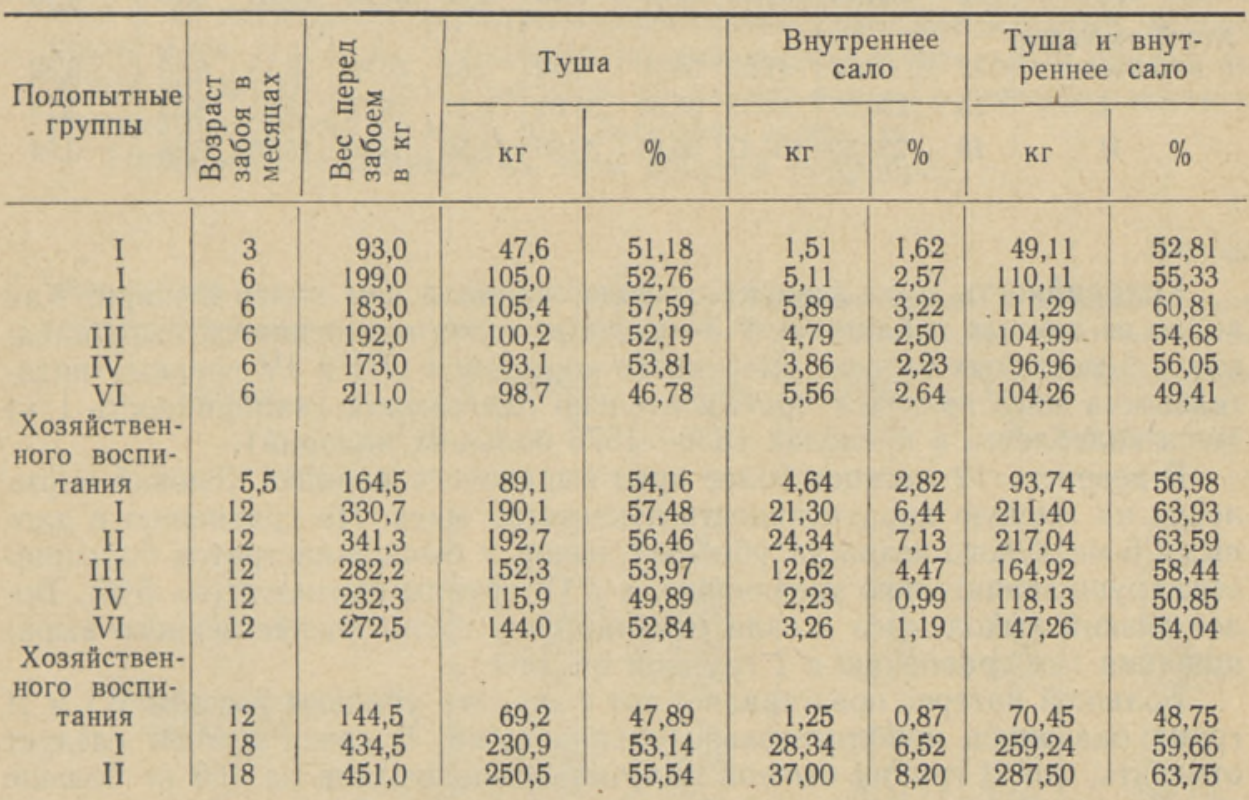

Результаты обвалки туш показывают (табл. 4), что удельный вес (в процентах) мяса и жира у 3-месячных телят, по сравнению с молодняком 6-месячного возраста обильного кормления (I и II группы), оказывается несколько меньшим. При этом обращает на себя внимание относи- 
тельно большое количество костей в тушках 3-месячных телят, что превышает этот же показатель у молодняка 6-месячного возраста умеренного кормления (III и IV группы).

Таблица 4

Результаты обвалки туш подопытных животных

\begin{tabular}{|c|c|c|c|c|c|c|c|c|c|c|}
\hline \multirow{2}{*}{$\begin{array}{c}\text { Подопытные } \\
\text { группы }\end{array}$} & \multirow{2}{*}{ 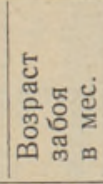 } & \multirow{2}{*}{$\begin{array}{c}\text { Туша } \\
\mathrm{Kг} \\
\end{array}$} & \multicolumn{2}{|c|}{ Мясо } & \multicolumn{2}{|c|}{ Жир } & \multicolumn{2}{|c|}{ Кости } & \multicolumn{2}{|c|}{$\begin{array}{c}\text { Сухожилия } \\
\text { в связки }\end{array}$} \\
\hline & & & kr & $\begin{array}{c}\% \text { от } \\
\text { веса } \\
\text { туши } \\
\end{array}$ & $\mathrm{kr}$ & \begin{tabular}{|c|}
$\%$ от \\
веса \\
туши
\end{tabular} & $\mathrm{K} \Gamma$ & $\begin{array}{|rr|}\% & \text { от } \\
\text { веса } \\
\text { туши }\end{array}$ & кг & $\begin{array}{l}\% \text { от ве- } \\
\text { са туши }\end{array}$ \\
\hline I & 3 & 47,06 & 30,40 & 63,87 & 0,77 & 1,62 & 13,55 & 28,47 & 2,40 & 5,04 \\
\hline I & 6 & 105,05 & 73,74 & 69,90 & 2,37 & 2,25 & 21,84 & 20,70 & 6,57 & 6,23 \\
\hline II & 6 & 105,40 & 72,26 & 68,56 & 3,70 & 3,51 & 23,46 & 22,26 & 5,78 & 5,48 \\
\hline III & 6 & 100,20 & 69,30 & 69,16 & 1,54 & 1,54 & 23,75 & 23,70 & 5,01 & 5,00 \\
\hline IV & 6 & 93,10 & 65,04 & 69,86 & 1,01 & 1,08 & 21,80 & 23,42 & 4,85 & 5,21 \\
\hline VI. & 6 & 98,70 & 67,00 & 67,88 & 1,84 & 1,86 & 24,65 & 24,97 & 4,73 & 4,79 \\
\hline $\begin{array}{c}\text { Хозяйственного } \\
\text { воспитания }\end{array}$ & 5,5 & 89,10 & 61,85 & 69,42 & 2,45 & 2,75 & 20,70 & 23,23 & 3,98 & 4,47 \\
\hline I & 12 & 190,10 & 122,27 & 64,32 & 24,19 & 12,72 & 35,00 & 18,41 & 7,76 & 4,08 \\
\hline II & 12 & 192,70 & 123,63 & 64,16 & 22,92 & 11,89 & 37,29 & 19,35 & 8,54 & 4,43 \\
\hline III & 12 & 152,30 & 104,00 & 68,29 & 9,40 & 6,17 & 31,10 & 20,42 & 6,90 & 4,53 \\
\hline IV & 12 & 115,90 & 81,10 & 69,97 & 1,20 & 1,04 & 26,90 & 23,21 & 5,80 & 5,00 \\
\hline VI & 12 & 144,05 & 102,00 & 70,81 & 3,45 & 2,40 & 31,80 & 22,08 & 6,10 & 4,23 \\
\hline $\begin{array}{c}\text { Хозяйственного } \\
\text { воспитания }\end{array}$ & 12 & 69,20 & 41,50 & 59,97 & 0,42 & 0,61 & 20,85 & 30,13 & 6,10 & 8,82 \\
\hline$I^{x}$ & 18 & 230,90 & 154,25 & 66,80 & 21,64 & 9,37 & 45,75 & 19,81 & 8,63 & 3,74 \\
\hline II & 18 & $|250,50|$ & 167,43 & 66,84 & 33,96 & 13,56 & 38,20 & 15,25 & 9,88 & 3,94 \\
\hline
\end{tabular}

Калорийность мяса зависит от содержания в нем влаги и жира. Как видно из данных таблицы 5 , у 3-месячных телят интенсивного выращивания и 6-месячных бычков умеренного кормления (III и IV группы) питательность мяса является приблизительно одинаковой (калорийность 1 кг мяса колеблется в пределах 1536-1576 больших калорий).

В возрасте 12 месяцев более ярко выразилось влияние условий кормления на мясную продуктивность и качество мяса. По сравнению с данными 6-месячного возраста убойный выход у бычков-кастратов большинства групп значительно увеличился, а у IV группы снизился (на 5\%). Более низкий выход мяса и сала отмечается у групп хозяйственного выращивания (по сравнению с I группой на 15\%).

Большой интерес представляет тот факт, что убойные выходы у I и II групп оказались приблизительно одинаковыми. В связи с этим следует отметить, что II группа бычков получила концентратов на 169 кг больше чем I; недополученные сильные корма у I группы были заменены картофелем. Свидетельством того, что эта замена оказалась весьма эффективной, служат цифры, приведенные в таблицах 4 и 5 . Из этих данных видно, что выход съедобной части туш (мясо + жир) и калорийность мяса у этих групп оказались практически одинаковыми.

Более низкий убойный выход у молодняка III и IV групп был обус- 
ловлен уменьшением выхода мяса и в особенности внутреннего сала. Так, у молодняка IV группы внутреннего сала было в 10-11 раз меньше, чем у I и II групп, а по весу IV группа уступала первым двум на $64-66 \%$ и по калорийности мяса - на $57-58 \%$.

В отношении бычков хозяйственного воспитания следует сказать, что у них внутреннего жира было в $17-19$ раз меньше, а вес туш в 2,8 раза меньше, чем у I и II групп. При этом убойный выход у них оказался лишь на $2 \%$ ниже, чем у молодняка IV группы.

Рассмотрение данных, приведенных в таблице 4, дает весьма важные сведения общебиологического характера.

У групп обильного кормления (I и II), наряду со значительным накоплением жировой ткани в тушах, отмечалось также усиленное развитие костной и мускульной тканей. Так, костная ткань у них была развита на $30-39 \%$, а мускульная - на $51-52 \%$ лучше, чем у молодняка IV группы. В сравнении с группой хозяйственного выращивания разница является еще более значительной. Таким образом в интересах использования потенциальных возможностей развития молодняка необходимо интенсивное выращивание его, при котором происходит образование в организме определенной доли жировой ткани.

В свете вышеприведенных данных выясняется, что встречающиеся в текущей зоотехнической литературе утверждения $\left({ }^{15}\right)$ о возможности хорошего развития молодняка без накопления в организме жировой ткани являются трудно осуществимыми на практике. Дополнительные данные по этому вопросу будут приведены ниже.

В возрасте 18 месяцев убойный выход (в процентах) по сравнению с предыдущим возрастом не увеличился. В абсолютных же показателях наблюдалось увеличение мяса, а при обильном кормлении концентратами повысилось также количество жира (у II группы). При этом, по сравнению с 12-месячными животными, несколько повысилась также калорийность мяса (табл. 5). Принимая во внимание значительный расход кормов в период от 12 до 18 месяцев, возникает вопрос о рентабельности выращивания бычков на мясо до 1,5 летнего возраста.

Ниже мы остановимся на этом вопросе подробнее.

Таблица 5

Химический состав мяса (вместе с жиром) подопытных бычков и бычков-кастратов

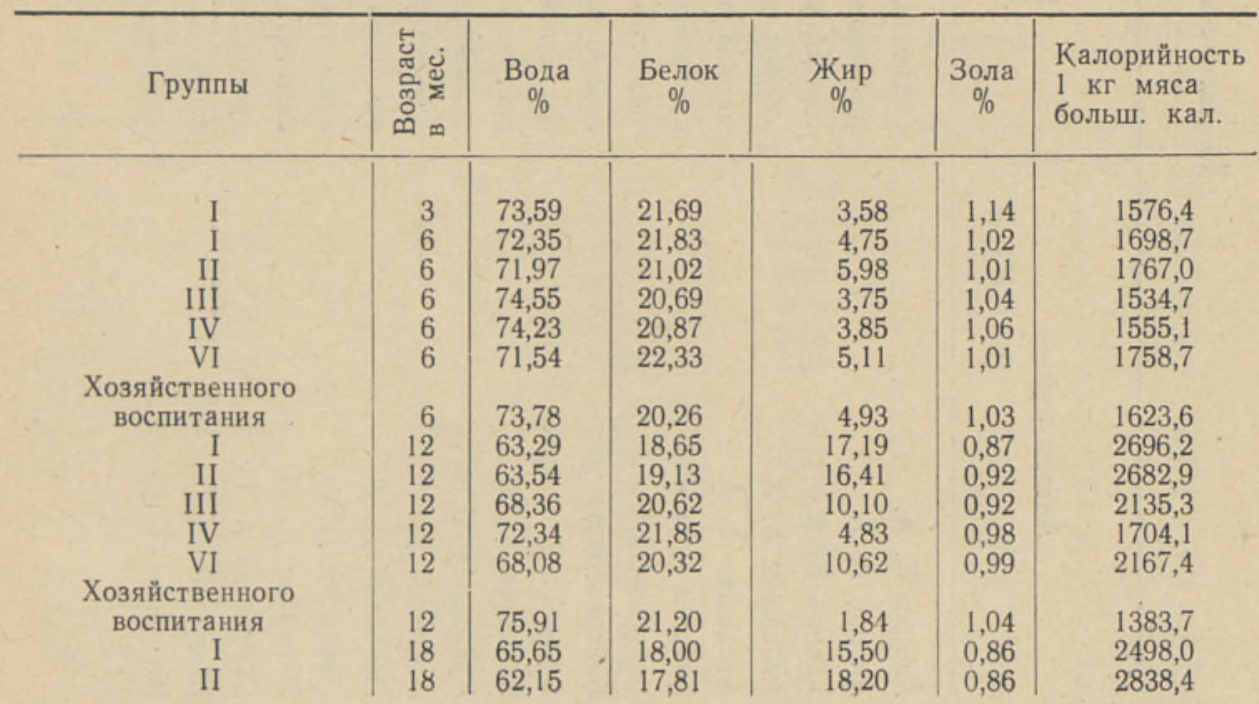


i.

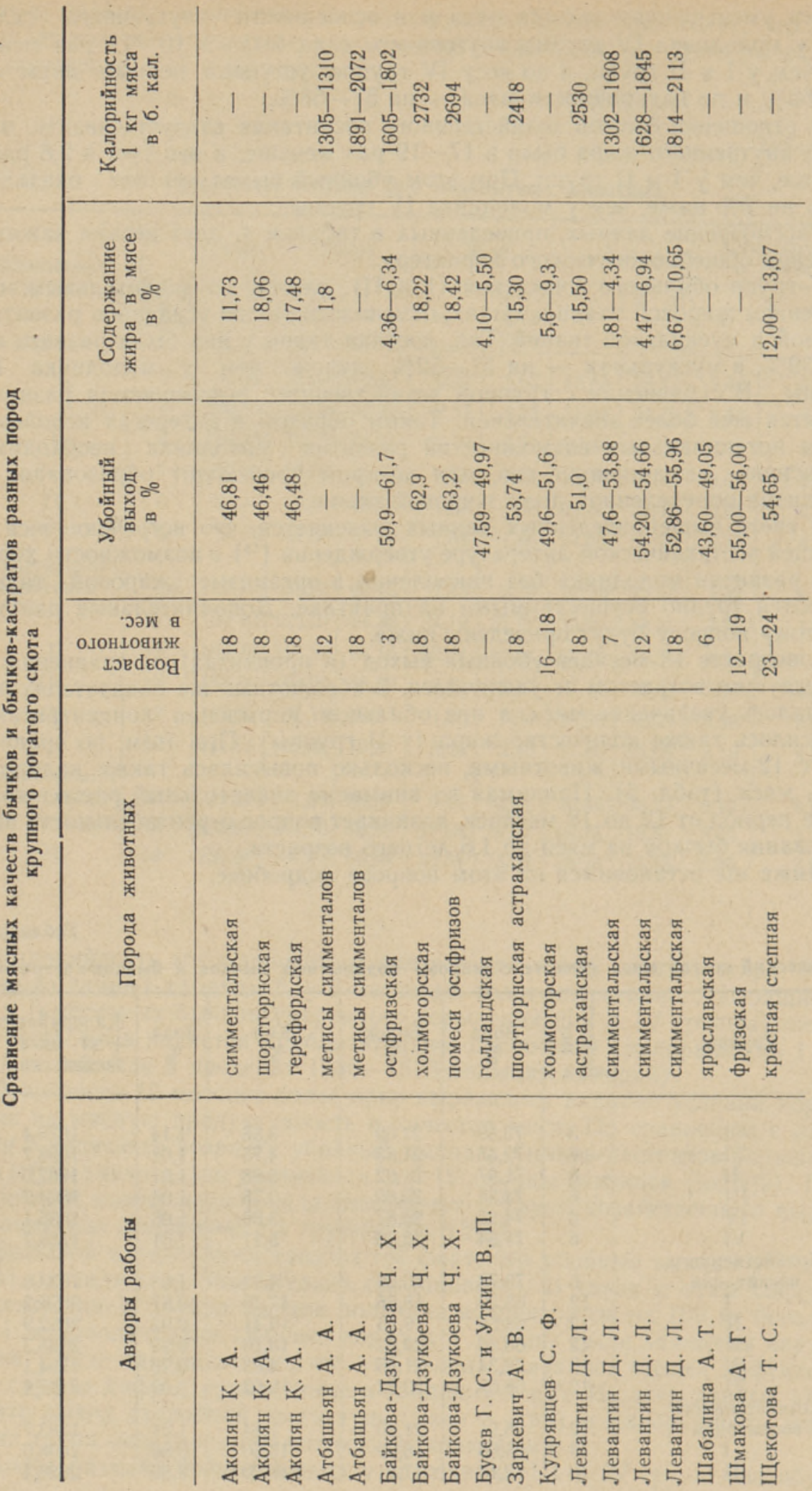


Сравнение результатов наших опытов с литературнымй данными (табл. 6) показывает следующее. Убойный выход и калорийность мяса эстонского красного скота до 6-месячного возраста, по сравнению с другими породами, являются вполне удовлетворительными. С возрастом эти качества улучшаются. Так, в возрасте 18 месяцев бычки мясных пород после нагула (по данным К. А. Акопяна (1)) отличались значительно меньшим убойным выходом, чем животные наших опытов.

Однако следует отметить то обстоятельство, что по сравнению с мясными и комбинированными породами у молодняка эстонского красного скота при обильном кормлении съедобная часть туши увеличивается в значительной степени за счет накопления жировой ткани.

Отличительной особенностью изучаемой породы является также и то, что жир откладывается на поверхности туши и между отдельными группами мышц весьма значительными прослойками, а не равномерно среди отдельных мускулов. Это явление, как нами уже было отмечено раньше $\left({ }^{2}\right)$, и служит причиной того, что мясо скота эстонской красной породы не приобретает мраморной структуры даже при обильном кормлении (фото 2), как это бывает у типичных мясных пород скота.

\section{Рост тканей и органов}

Обобщая данные по росту тканей у подопытных животных, необходимо обратить внимание на следующее (табл. 7). Костная ткань к 3-месячному возрасту увеличилась в 2,2 раза, а в период с 3 до 6 месяцев от 1,6 (I и II группы) до 1,8 раза (VI группа), с 6 до 12 месяцев от 1,2 (IV группа) до 1,6 раза (I группа) и с 12 до 18 месяцев от 1,3 (I группа) до 1,03 раза (II группа). Из этих данных видно, что после 6-месячного возраста скелет продолжает развиваться еще сравнительно интенсивно. Наименьшие коэффициенты роста костяка наблюдаются при этом у групп умеренного и среднего уровня кормления.

таблича 7

Коэффициент роста тканей в тушах подопытных животных

\begin{tabular}{|c|c|c|c|c|c|}
\hline $\begin{array}{c}\text { Подопытные } \\
\text { группы }\end{array}$ & 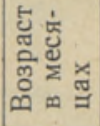 & Кости & $\begin{array}{c}\text { Мускульная } \\
\text { ткань }\end{array}$ & $\begin{array}{c}\text { Жировая } \\
\text { ткань }\end{array}$ & $\begin{array}{c}\text { Соедини- } \\
\text { тельная } \\
\text { ткань }\end{array}$ \\
\hline I & $\begin{array}{l}2 \\
3 \\
6 \\
6 \\
6 \\
6 \\
6\end{array}$ & $\begin{array}{l}1,00 \\
2,17 \\
3,50 \\
3,76 \\
3,81 \\
3,50 \\
3,96\end{array}$ & $\begin{array}{l}1,00 \\
2,73 \\
6,62 \\
9,49 \\
6,22 \\
5,84 \\
6,01\end{array}$ & $\begin{array}{l}-1,00 \\
3,08 \\
4,80 \\
2,00 \\
1,31 \\
2,39\end{array}$ & $\begin{array}{r}1,00 \\
3,81 \\
10,43 \\
9,13 \\
7,95 \\
7,70 \\
7,51\end{array}$ \\
\hline $\begin{array}{c}\text { Хозяйственного } \\
\text { воспитания } \\
\text { I } \\
\text { II } \\
\text { III } \\
\text { IV } \\
\text { VI } \\
\text { Хозяйственного }\end{array}$ & $\begin{array}{l}5-6 \\
12 \\
12 \\
12 \\
12 \\
12\end{array}$ & $\begin{array}{l}3,32 \\
5,62 \\
5,98 \\
4,99 \\
4,32 \\
5,10\end{array}$ & $\begin{array}{r}5,55 \\
10,97 \\
11,10 \\
9,34 \\
7,28 \\
9,16\end{array}$ & $\begin{array}{r}3,18 \\
31,41 \\
29,77 \\
12,21 \\
1,56 \\
4,48\end{array}$ & $\begin{array}{r}6,32 \\
12,32 \\
13,55 \\
10,95 \\
9,21 \\
9,68\end{array}$ \\
\hline $\begin{array}{c}\text { воспитания } \\
\text { I } \\
\text { II }\end{array}$ & $\begin{array}{l}12 \\
18 \\
18\end{array}$ & $\begin{array}{l}3,35 \\
7,34 \\
6,13\end{array}$ & $\begin{array}{r}3,72 \\
13,85 \\
15,03\end{array}$ & $\begin{array}{r}0,54 \\
28,10 \\
44,10\end{array}$ & $\begin{array}{r}9,68 \\
13,70 \\
15,68\end{array}$ \\
\hline
\end{tabular}


Иной характер роста отмечается в отношении мускулатуры. С момента рождения и до 3-месячного возраста мускульная ткань увеличилась в 2,7 раза, в период с 3 до 6 месяцев от 2,1 до 2,4 раза, с 6 до 12 месяцев от 1,3 до 1,7 раза и с 12 до 18 месяцев от 1,3 до 1,4 раза. Таким образом, увеличение мускулатуры до 6-месячного возраста шло значительно быстpeе, чем рост костяка. В период от 6 до 12 месяцев эти виды тканей росли почти одинаково интенсивно. От 12 до 18 месяцев у I группы преобладал рост костяка, а у II группы - увеличение мускулатуры.

Образование жировой ткани до 3-6-месячного возраста шло относительно слабо даже при обильном кормлении. В период же от 6 до 12 месяцев по сравнению с 3-месячными телятами интенсивность образования жировой ткани при обильном кормлении увеличилась в несколько десятков раз. При этом обращает на себя внимание слабое накопление жира у групп молодняка умеренного и скудного кормления. При сопоставлении коэффициентов роста тканей видно, что между ними существует положительная корреляция, т. е. при хорошем развитии ткани одного вида наблюдается также более интенсивное развитие других ее видов. Следует отметить, что образование мускулатуры связано с накоплением жира в организме более тесно, чем рост костяка. Другими словами, умеренное и скудное кормление отражается на росте скелета менее резко, чем на образовании мускульной и в особенности жировой тканей. Эти закономерности должны быть обнаружены также в ходе развития внутренних органов.

Если сравнить рост сердца у различных групп молодняка в годовалом возрасте, то видно, что сердце у бычков IV группы в 2 раза легче, чем у представителей II группы (табл. 8, фото 3 ).

Tаблица 8

Величина органов у бычков и бычков-кастратов в возрасте 12 и 18 месяцев

\begin{tabular}{|c|c|c|c|c|c|c|c|c|}
\hline \multirow[t]{2}{*}{ Возраст и группы } & \multicolumn{5}{|c|}{12 месяцев } & \multirow{2}{*}{ 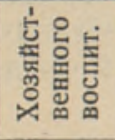 } & \multicolumn{2}{|c|}{18 месяцев } \\
\hline & I & II & III & IV & VI & & I & II \\
\hline 1. Кровь & 13,60 & 14,20 & 10,10 & 8,60 & 10,45 & 6,15 & 18,36 & 15,60 \\
\hline 2. Сердце & 1,65 & 1,87 & 1,23 & 0,88 & 1,37 & 0,87 & 2,20 & 1,76 \\
\hline 3. Легкие & 2,58 & 2,65 & 2,41 & 1,98 & 2,96 & 1,53 & 3.40 & 3,14 \\
\hline 4. Печень & 4,26 & 5,16 & 3,60 & 2,80 & 2,80 & 2,25 & 5,40 & 5,39 \\
\hline 5. Почки & 0,88 & 1,09 & 0,80 & 0,60 & 0,75 & 0,70 & 1,37 & 1,16 \\
\hline 6. Селезенка . . & 0,61 & 0,62 & 0,74 & 0,41 & 0,57 & 0,37 & 0,82 & 0,68 \\
\hline 7. Рубец и сетка & 6,10 & 7,43 & 6,10 & 5,70 & & 3,91 & 9,60 & 9,77 \\
\hline 8. Книжка . . & 2,45 & 2,08 & 1,80 & 1,60 & 2,30 & 1,46 & 2,50 & 2,21 \\
\hline 9. Сычуг & 1,21 & 1,31 & 1,20 & 1,30 & 1,10 & 0,78 & 1,82 & ,38 \\
\hline 10. Тонкие кишки & 4,30 & 4,79 & 3,90 & 3,20 & & 3,20 & 4,60 & 4,56 \\
\hline 11. Толстые кишки . . . & 1,88 & 2,06 & 2,40 & 2,20 & 3,05 & 2,10 & 2,20 & 2,30 \\
\hline 12. Объем рубца и сетки. л & 83,00 & 64,00 & 61,00 & 54,90 & 46,60 & 36,12 & $\bullet 89,23$ & 99,50 \\
\hline 13. Объем сычуга . . & 8,00 & 6,30 & 5,70 & 5,20 & 7,00 & 4,40 & 8,51 & 7,70 \\
\hline 14. Длина тонких кишек .. м & 37,70 & 37,00 & 35,90 & 34,60 & 37,80 & 32,08 & 48,65 & 41,80 \\
\hline 15. Длина толстых кишек . , & 8,20 & 8,12 & 8,50 & 7,60 & 7,80 & 6,75 & 9,46 & 10,10 \\
\hline 16. Кожа . . . . . кг & 18,80 & 21,70 & 16,40 & 12,40 & 18,90 & 9,40 & 27,55 & 29,80 \\
\hline 17. Площадь кожи . . . д дм² & 312 & 335 & 278 & 216 & 246 & 193 & 339,50 & 377 \\
\hline
\end{tabular}




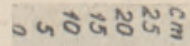

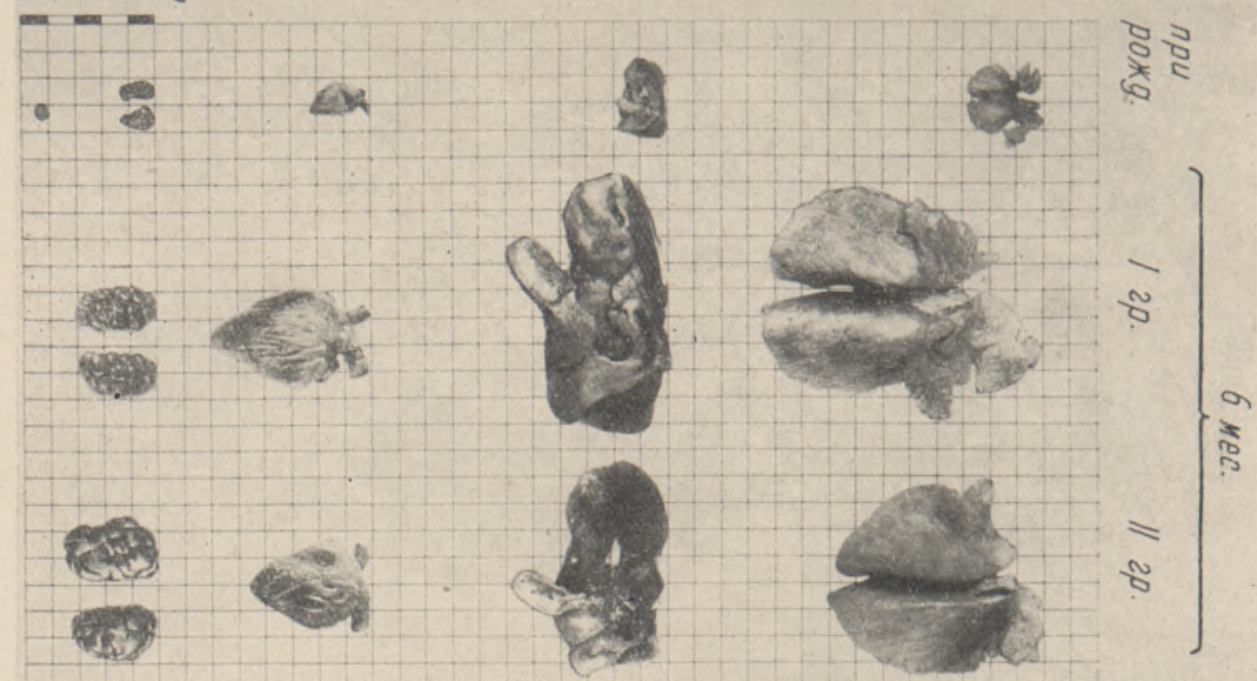

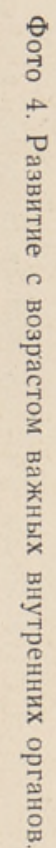
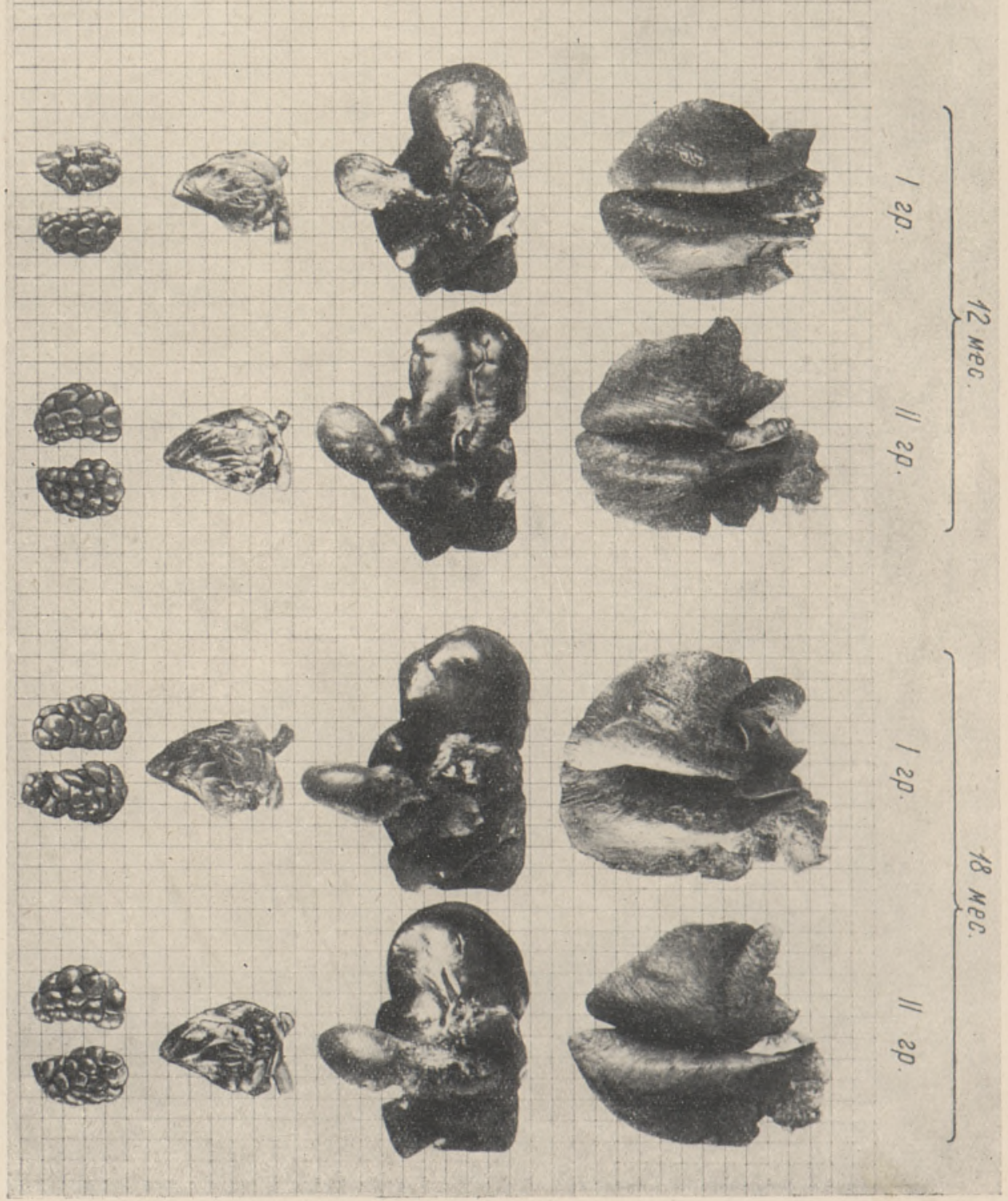
Рост сердца, повидимому, связан с количеством крови в организмѐ. Как самым большим сердцем, так и наибольшим количеством крови отличался молодняк II группы (14,2 кг), ниже всего эти показатели были y IV группы $(8,6$ кг), а животные хозяйственного воспитания отставали от них еще больше.

В отношении роста легких и печени наблюдалось такое же положение, какое было отменено для сердца. Из пищеварительных органов рубец и сетка являются наиболее крупными также у II группы. Наибольший же объем этих органов наблюдался у молодняка I группы. Развитие книжки, сычуга и тонких кишек, как и преджелудков, связано с уровнем кормления и зависело в наших опытах от количества сухого вещества, съеденного животными. Самый большой вес толстых кишек наблюдался у животных VI группы, а наибольшая длина этих органов - у III группы. На размер почек повлиял общий уровень кормления и особенно.уровень протеинового кормления. Ярко отразился уровень кормления и на развитии кожи. В 12-месячном возрасте наибольший вес кожи отмечался у животных II группы (21,7 кг против 12,4 и 9,4 кг у IV группы и бычков хозяйственного выращивания). Небольшую и тонкую кожу имели животные умеренного и в особенности скудного кормления. Таким образом для получения высококачественного кожевенного сырья большое значение имеет уровень и тип кормления животных.

По поводу динамики роста органов необходимо 'сказать следующее. Большинство внутренних органов росло наиболее интенсивным темпом от рождения до 3-месячного возраста (увеличение веса от 1,2 до 4,7 раза). Чрезвычайно быстро увеличились рубец и сетка, как по весу (в 7,8 раза), так и поо объему (в 23 раза). Аналогичное положение наблюдается и в отношении книжки (увеличение по весу в 12 раз). Исключение составляло развитие толстых и тонких кишек, самое интенсивное увеличение веса которых (в 3 раза) наблюдалось в период от 3 до 6 месяцев, что совпадает с наибольшим увеличением общего веса животных, которое имело место в этот же период. Следует особо отметить, что относительно интенсивным темпом продолжали развиваться органы пищеварения как во второй половине года, так и на втором году жизни. Такие органы, как сердце, легкие, печень также продолжали расти сравнительно интенсивно, однако наиболее быстрым темпом они увеличились от рождения животного и до 6-месячного возраста (фото 4). Как правило, коэффициенты роста органов у IV группы и, в частности, у бычков хозяйственного выращивания оказались значительно меньшими, чем у представителей остальных групп. Как мы уже видели выше, жировая ткань у них также была развита слабо. Таким образом, максимальный рост внутренних органов взаимосвязан с образованием определенного количества жировой ткани в организме молодняка.

Несколько иная картина наблюдается при сравнении отношения органов и тканей к весу тела молодняка. У подопытных групп умеренного кормления (III и IV группы) в возрасте 12 месяцев кровь и сердце имели по отношению к общему весу тела менышие, а легкие, сычуг и толстые кишки более высокие показатели, чем у молодняка I и II групп. У бычков же хозяйственного выращивания в этом же возрасте все органы, кровь и кожа оказались в отношении живого веса лучше развитыми, чем у остальных групп молодняка (в частности III и IV). Отсюда видно, что при недостаточном кормлении внутренние органы по сравнению с весом тела имели относительно больший вес.

Из данных соотношения веса органов к весу тела молодняка видно также, что самый большой относительный вес имели кишки, сердце, сычуг и кожа в первые дни постэмбрионального периода. Преджелудки к 
моменту рождения оказались слабо развитыми органази, но с первых дней жизни до 1,5-годовалого возраста их вес увеличивался относительно более быстрыми темпами, чем вес тела молодняка. Первое положение является вполне понятным, т. к. новорожденный теленок по природным потребностям питается молоком; переход теленка из тела матери к непосредственному контакту с внешней средой ставит перед его сердцем и кожей очень большие задачи. Во втором положении заключается возможность путем соответствующего кормления повлиять на развитие преджелудков в желательную сторону и способствовать большему потреблению и переработке местных основных кормов.

\section{Экономические вопросы выращивания бычков на мясо}

Для объективного суждения о выгодности забоя бычков различного возраста и различной упитанности на мясо необходимо прежде всего произвести экономический анализ стоимости израсходованных кормов (съеденные корма были в точности учтены).

Денежная стоимость кормов, израсходованных для выращивания бычков, оказалась наименьшей у III группы как до 6-месячного, так и до годовалого возраста (табл. 9). ${ }^{1}$ Кормление же бычков IV группы до 6-месячного возраста, ввиду отсутствия в рационах снятого молока, обходилось на $21 \%$ дороже, чем кормление бычков I группы и на $48 \%$ дороже бычков III группы. Наиболее удачное с экономической точки зрения сочетание кормов имело место, повидимому, у III группы (хотя у животных этой группы и наблюдалась самая низкая калорийность мяса, но убойный выход оказался у них совершенно удовлетворительным).

Наибольшие расходы были связаны с кормлением бычков II группы (на $10-63 \%$ больше, чем у остальных). В связи с этим интересно установить, каков удельный вес отдельных кормов в общей стоимости последних. На основе данных таблицы 9 можно вычислить, что от общей стоимости кормов на цельное молоко пришлось при забое бычков в 3-месячном возрасте $95 \%$, в 6-месячном возрасте - от 67 (III группа) до $82 \%$ (IV и VI группы), в годовалом возрасте - от 36 (I группа) до 60\%. (IV группа), а при забое животных в возрасте 18 месяцев - 26-27\%. Стоимость концентратов составляла в этих возрастах соответственно около $3 \%, 8 \%$ (VI группа) - 17\% (III группа), $13 \%$ (IV группа) - 26\% (II группа) и $22-23 \%$ (I и II группы). Из приведенных данных ярко видно, что большинство расходов связано с цельным молоком и концентратами. Снятое же молоко и зеленые корма составляют незначительную часть от общей стоимости скормленных кормов. Қак было установлено нашими исследованиями о переваримости корма и обмене веществ у молодняка, биологическая ценность этих дешевых кормов оказалась весьма высокой $\left({ }^{3,4}\right)$.

Таким образом, при выращивании сверхремонтного молодняка на мясо (если такой способ производства мяса при нынешнем состоянии кормовой базы в хозяйствах и существующих закупочных ценах вообще является хозяйственно выгодным) следует экономить цельное молоко, заменяя его снятым при одновременном скармливании животным обильного количества сочных и зеленых кормов.

1 При этих вығислениях использовались данные себестоимости кормов совхоза «Трийги» Министерства совхозов ЭССР. 
Стоимость кормов, израсходованных на кормление бычков

(в среднем на одно животное в рублях)

\begin{tabular}{|c|c|c|c|c|c|c|c|c|c|c|c|}
\hline \multirow[t]{2}{*}{ Корма } & \multicolumn{2}{|c|}{ Молоко } & \multirow{2}{*}{ 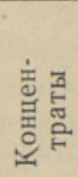 } & \multirow{2}{*}{ 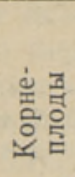 } & \multirow[b]{2}{*}{ 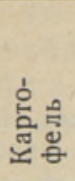 } & \multirow[b]{2}{*}{$\begin{array}{l}\stackrel{0}{0} \\
\text { J゙ }\end{array}$} & \multirow[b]{2}{*}{ ن̊ } & \multirow{2}{*}{$\begin{array}{l}\frac{\pi}{2} \\
\text { o. } \\
\text { jँ }\end{array}$} & \multirow{2}{*}{ 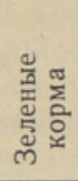 } & \multirow{2}{*}{ 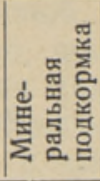 } & \multirow{2}{*}{ 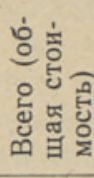 } \\
\hline & Цельное & Снятое & & & & & & & & & \\
\hline
\end{tabular}

$0-3$ месяцев

I $|386.97| 8.23|10.66|-|-|-|0.52|-|1.85| 0.20 \mid 408.43$

$0-6$ месяцев

\begin{tabular}{r|r|c|c|c|c|c|r|r|r|r|r} 
I & 386.97 & 22.95 & 81.67 & 11.26 & 4.80 & - & 17.45 & - & 11.50 & 1.02 & 537.62 \\
II & 576.02 & 27.88 & 80.23 & 3.20 & - & - & 15.30 & - & 13.12 & 1.02 & 716.77 \\
III & 297.32 & 22.09 & 75.35 & - & 15.79 & - & 6.00 & - & 23.75 & 0.61 & 440.91 \\
IV & 532.03 & - & 76.01 & 8.92 & - & - & 16.25 & - & 17.11 & 0.82 & 651.14 \\
VI & 476.92 & 27.27 & 46.53 & 0.35 & - & - & 0.61 & - & 29.52 & 0.18 & 581.38
\end{tabular}

$0-12$ месяцев

\begin{tabular}{r|r|r|r|r|r|r|r|r|r|r|r} 
I & 386.97 & 24.76 & 229.06 & 130.28 & 190.51 & - & 110.65 & 0.69 & 12.24 & 4.38 & 1085.45 \\
II & 576.02 & 30.26 & 297.00 & 104.56 & 2.40 & - & 120.51 & 0.37 & 13.12 & 4.62 & 1148.86 \\
III & 297.32 & 23.89 & 167.19 & 67.84 & 20.18 & - & 103.05 & - & 34.09 & 1.61 & 715.17 \\
IV & 532.03 & - & 114.67 & 92.73 & 22.24 & 5.00 & 98.34 & - & 25.04 & 1.72 & 891.77 \\
VI & 476.92 & 27.32 & 123.32 & 57.72 & 2.60 & 9.78 & 83.04 & - & 41.23 & 1.74 & 823.67
\end{tabular}

$0-18$ месяцев

\begin{tabular}{r|r|r|r|r|r|r|r|r|r|r|r} 
I & 386.97 & 24.76 & 321.72 & 167.08 & 274.27 & - & 165.00 & 0.69 & 107.39 & 8.04 & 1465.92 \\
II & 576.02 & 30.26 & 522.58 & 157.60 & 19.44 & - & 164.00 & 0.37 & 89.47 & 8.06 & 1567.80
\end{tabular}

Вышеприведенные расчеты не дают сведений о стоимости единицы (кг, 1000 б. кал.) мясной продукции. Представление о последней можно получить из таблиц 10 и 11. Как видно из этих таблиц, наивысшая стоимость производства 1 кг мяса и сала наблюдалась при забое бычков в возрасте 3 месяцев.

Таблица 10

Расход кормов на производство 1 кг мяса и сала

(в среднем на одно животное в рублях)

\begin{tabular}{r|r|r|r|c}
\hline $\begin{array}{l}\text { Возраст } \\
\text { забоя в мес. }\end{array}$ & 3 & & & 12 \\
\hline
\end{tabular}

5 ENSV Tead. Akad. Toimetised; biol. s. 3 
Наиболее дешевым оказался, таким образом, 1 кг мяса и сала прин забое бычков на мясо в возрасте $12-18$ месяцев, хотя по отдельным группам и наблюдаются некоторые колебания. Расчет стоимости 1000 б. кал. в мясе и сале (т. е. общей питательности полученных продуктов) дает

Таблица 11

Расход кормов на производство 1000 б. кал. в мясе и сале (в среднем на одно животное в рублях)

\begin{tabular}{|c|c|c|c|c|}
\hline$x^{x}$ & 3 & -6 & $12=$ & 18 \\
\hline $\begin{array}{l}\text { I } \\
\text { II } \\
\text { III } \\
\text { IV } \\
\text { VI }\end{array}$ & $\begin{array}{l}8.32 \\
\text { 二 } \\
-\end{array}$ & $\begin{array}{l}4.16 \\
5.34 \\
4.54 \\
6.34 \\
4.80\end{array}$ & $\begin{array}{l}2.55 \\
2.92 \\
2.96 \\
6.36 \\
3.60\end{array}$ & $\begin{array}{l}3.42 \\
2.74 \\
- \\
-\end{array}$ \\
\hline Всего & 8.32 & 5.04 & 3.68 & 3.08 \\
\hline
\end{tabular}

приблизительно аналогичную картину. У большинства групп (кроме IV) наиболее дешевым оказалось производство 1000 б. кал. в мясе и сале при забое бычков в возрасте 12 и 18 месяцев. Производство каждой 1000 б. кал. в мясе и сале 3-месячных бычков обошлось в 2,3 раза дороже, чем у бычков 12-месячного возраста (I группа). Это объясняется тем, что для кормления молодняка до 3-месячного возраста применяются в основном такие дорогостоящие корма, как цельное молоко и концентраты. После этого срока, а особенно после 6-месячного возраста увеличение мясной продукции и калорийности мяса происходит главным образом за счет грубых и сочных кормов.

Обращает на себя внимание тот факт, что у IV группы бычков расходы на производство 1000 б. кал. в мясе и сале по сравнению с остальными группами (кроме VI) оказались примерно в 2 раза выше. Вызвано это в частности сравнительно низким уровнем протейнового кормления (одностороннее кормление основными кормами).

Таким образом, стоимость производства каждого килограмма мяса и жира или каждой 1000 б. кал. является наименьшей при хорошем кормлении балансированными рационами и при забое животных в возрасте 12-18 месяцев. При этом следует, однако, иметь в виду то обстоятельство, что абсолютное количество кормов, необходимых для выращивания молодняка до более старших возрастов, значительно увеличивается. Кроме того, надо учитывать также и то, сколько б. кал. можно производить в молоке, расходуя для этой цели соответствующие количества кормов.

Исходя из того, что на каждую кормовую единицу можно получать от молочной коровы около $1 \mathrm{kr}$ молока с жирностью $4 \%$, то за счет кормов (в том числе цельное и снятое молоко), скормленных каждому бычку различных групп, например, до 12-месячного возраста, можно было бы производить от 1115 до 1849 кг молока, а за счет кормов, скормленных до 1,5 лет - от 2844 до 3042 кг молока с жирностью $4 \%$. Калорийность этих количеств молока составляет: в первом случае от 847400 до 1405200 б. кал., во втором - от 2161440 до 2311920 б. кал. 
При забое 12 -месячных бычков различных группп в мясе и жире ${ }^{1}$ фактически производилось от 140247 (IV группа) до 394885 б. кал. (II группа), а при забое полуторагодовалых - от 439373 (I группа) до 571625 б. кал. в среднем на каждое животное.

Из приведенного будет ясно, что коровы эстонской красной породы гораздо более эффективно перерабатывают корма в молоко, чем бычки этой же породы превращают корма в мясо и жир (учитывая даже и то, что кровь и внутренние органы имеют определенную пищевую ценность).

Следовательно, при наблюдающемся в настоящее время в хозяйствах недостатке хороших грубых и сочных кормов, а также учитывая существующие закупочные цены и необходимость повышения производства молока, бычков (и вообще сверхремонтный молодняк) необходимо отправлять на мясокомбинаты в возможно более раннем возрасте, но хорошо упнтанными.

\section{Выводы}

У подопытных групп молодняка высокого уровня кормления (I и II группы) съедоб́ная часть туш и калорийность мяса увеличивались к годовалому возрасту до степени, характерной для комбинированных и даже мясных пород скота. При этом в тушах наблюдалось относительно большее увеличение жира, чем мяса, а также накопление жира на поверхности туш и его отложение прослойками между отдельными группами мышц. Ввиду отсутствия равномерного распределения жира между мускульными волокнами, мясо у изучаемой породы не характеризуется «мраморной» структурой даже при обильном кормлении животных.

У подопытных групп более умеренного кормления (III и IV группы) в годовалом возрасте против 6-месячного возраста увеличение съедобной части туш, по сравнению с костяком и сухожилиями, было менее выражено или совсем отсутствовало (у IV группы). При забое 1,5-годовалых бычков (по сравнению с 12-месячными животными) можно было добиться еще незначительного увеличения убойного выхода (при израсходовании больших количеств кормов).

Максимальная скорость роста костяка животных наблюдалась в период от рождения до 3-месячного возраста (увеличение в 2,2 раза).

Рост мышечной ткани, по сравнению с костяком, протекал несколько более усиленным темпом до 6-месячного возраста, после чего они развивались почти с одинаковой скоростью до 12-месячного возраста.

В общей сложности образование жировой ткани до 6-месячного возраста имеет второстепенное значение даже при обильном кормлении, так как питательные вещества в этом возрастном периоде используются главным образом на рост скелета, мускулатуры и внутренних органов.

Рост важных внутренних органов и крови оказался аналогичен развитию скелета и мышечной ткани; наибольшая скорость увеличения их веса наблюдалась до 3-месячного возраста. Самый интенсивный рост кишек наблюдался в период от 3 до 6 месяцев, что совпадает с наибольшими среднесуточными привесами в этот период. Увеличение веса сердца и печени было теснейшим образом связано с количеством крови в организме.

В общей сложности, в интересах хорошего роста скелета, мускулатуры и внутренних органов после 6-месячного возраста необходимы такой тип и уровень кормления, которые обеспечивали бы образование некоторой доли жировой ткани в организме (общебиологическое заключение).

1 Калорийность внутренних органов и крови не определялась. 
Если не учи́тывать этого об̆стоятельства, піотенцйальные возможности развития молодняка эстонской красной породы в интересах повышения его скороспелости и укрупнения животных не будут использованы.

Увеличение убойного выхода и калорийности мяса будет обеспечено при такой интенсивности выращивания бычков, при которой живой вес прєвышает требования бонитировки класса элита-рекорд (на $10-15 \%$ ).

Производство единицы (кг, 1000 б. кал.) мясной продукции является наиболее дешевым (до 2 раз) при кормлении молодняка рационами, содержащими различные корма в оптимальных (для данного возраста) количествах и соотношениях и при забое животных в возрасте 12-18 месяцев.

Ввиду того, что молочные коровы эстонской красной породы гораздо более эффективно перерабатывают корма в молоко, чем молодняк изучаемой породы превращает питательные вещества в мясо и жир (расчеты проведены на основе калорийности молочной и мясной продукции), а также учитывая состояние кормовой базы (в каждом конкретном хозяйстве) и закупочные цены на мясо, сверхремонтный молодняк следует отправлиять на мясокомбинаты в возможно более раннем возрасте, но хорошо упитанным.

При откорме сверхремонтного молодняка необходимо шире применять такие дешевые, но биологически полноценные корма, как снятое молоко, сочные и зеленые корма.

Институт животноводства и ветеринарии Академии наук Эстонской ССР
Поступила в редакцию 15 VII 1955

\section{ЛИТЕРАТУРА}

1. Акопян К. А., Сравнение мясных качеств бычков-кастратов разных пород при нагуле их на естественных выпасах юго-востока СССР. «Вестник животноводства», вып. 3, 1947.

2. А ранди П. Я., Опыт интенсивного выращивания молодняка крупного рогатого скота эстонской красной породы. «Изв. АН ЭССР», т. I, № 4, 1952.

3. А р а нди П. Я., Переваримость питательных веществ рационов молодняком эстонской красной породы скота в зависимости от типа и уровня кормления. «Изв. АН ЭССР, т. III, № 3,1954 .

4. А р а нд и П. Я., Усвояемость азота (протеина) корма молодняком крупного рогатого скота эстонской красной породы. «Изв. АН ЭССР», т. III, № 4, 1954.

5. А т б а шьян А. А., Изменения в организме молодняка крупного рогатого скота под влиянием разных типов питания. Диссертация. Москва, 1949.

6. Ба й ков а - Д з укое ва Ч. Х., Мясные качества молодняка холмогорской и остфризской пород. Диссертация. Москва, 1952.

7. Бу се в Г. С. и Уткин В. П., Откорм молодняка крупного рогатого скота на сочных кормах при минимуме концентратов. «Труды Всесоюзного научного исследовательского института животноводства», т. 18, 1950.

8. Герчи ков Н. П., Развитие бычков, кастрированных в различном возрасте. «Социалистическое животноводство», № 4, 1940.

9. К удр я вц е в С. Ф., Выращивание и нагул молодняка крупного рогатого скота. «Животноводство», № $4,1953$.

10. Л ев а нтин Д. Л., Влияние породы и кровности на мясные качества молодняка. Диссертация. Москва, 1947.

11. Лев антин Д. Л., Влияние питания на мясную продуктивность молодняка крупного рогатого скота. «Мясная индустрия СССР», № 4, 1950.

12. Шаб алин а А. Т., Рост и развитие молодняка ярославской породы при разных типах рационов. Диссертация. Москва, 1952.

13. Ш м а ков а А. Г., Рост и развитие телят остфризской породы при различном типе кормления. Сб. трудов Ленинградской областной с.-х. оп. станции, № 23, 1953.

14. Щ е котов а Т. С., Влияние типа воспитания красного степного скота и его помесей на развитие, продуктивность и использование кормов. Диссертация. Аскания-Нова, 1952.

15. Ю р м а ли а т А. П. и Бегучев А. П., Очередные вопросы выращивания телят. єСоветская зоотехния», № 4, 1949. 


\title{
EESTI PUNAST TOUUG NOORPULLIDE JA NOORTE PULL- KASTRAATIDE LIHAOMADUSED, KUDEDE JA ORGANITE ARENG MITMESUGUSTE SÖÖTMISTINGIMUSTE PUHUL
}

\author{
P. ARANDI, \\ pöllumajandusteaduste doktor \\ Resümee
}

Eesti punase karja noorveiste lihaomaduste, kudede ja organite kasvu uurimiseks tapeti mitmesuguses vanuses (otse sünnijärgselt, 3-, 6-, 12- ja 18-kuuselt) erinevates söötmise tingimustes kasvatatud 42 looma, mis kuulusid viide katserühma.

Intensiivselt söödetud rühmades ulatub 6-kuuste pull-kastraatide tapakaal kuni 110 kg-ni, 12- ja 18-kuuselt vastavalt 217 ja $287 \mathrm{~kg}$-ni, mis moodustab eluskaalust $60-64 \%$. Siseelundite rasvakogus moodustab eluskaalust 6 -kuuselt kuni $3 \%, 12$ - ja 18 -kuuselt vastavalt $7-8 \%$. Lihakeha rasvasisaldus 6 -kuuselt ulatub 3,5\%-ni, 12 - ja 18 -kuuselt $12,7-13,6 \%$-ni. Liha kilogrammi kalorsus intensiivse söötmise puhul kõigub 2500-2800 kcal piirides. Seega ulatub liha ja rasva toodang uuritud noorveistel tasemele, mis on karakteerne kombineeritud ja isegi lihaveiste tõugudele. Eesti punasel veisetõul deponeerub rasv (peale siseelundite rasva) lihakeha pinnal ja üksikute lihaste vahel suuremate või väiksemate ribadena ega jagune ühtlaselt lihaskiudude vahel; seetõttu, valatamata intensiivsele söötmisele, ei ole lihal «marmorset» struktuuri, nagu see on iseloomulik lihaveise tõugudel.

Mõõduka, eriti aga puuduliku söötmise puhul kasvatatud rühmades oli lihakeha kaal ja rasvasisaldus kehas kuni $50 \%$ võrra ja üle selle madalam kui intensiivselt söödetud rühmades (andmed 6- ja 12-kuuste loomade kohta). Mõõduka söötmise korral suureneb lihakeha inimtoiduks minev osa vanusega suhteliselt vähem, kuna luustiku ja kõõluste osatähtsus moodustab $23-30 \%$, ratsionaalse söötmise korral vastavad näitajad aga ei ületa $18-19 \%$ (andmed 12- ja 18-kuuste loomade kohta).

Luustiku, lihaste ja siseorganite kõige intensiivsem kasv toimub sünnist kuni 6 kuu vanuseni. Rasvkoe moodustumine nimetatud vanuseperioodil on tagasihoidlik isegi rikkaliku söötmise tingimustes. Rikkaliku söötmise korral esimese eluaasta teisest poolest alates rasva deponeerimise ulatus võrreldes varase sünnijärgse perioodiga suureneb 10 -kordselt ja isegi rohkem.

Mõõduka söötmise puhul väheneb skeleti ja tähtsate siseelundite kasvukiirus väiksemal määral kui lihaste areng ja rasvkoe teke; nii luustik kui ka siseelundid, samuti lihased on heas toitumusseisundis olevatel loomadel maksimaalselt arenenud.

Tapakaalu, liha ja rasva tootmise maksimaalne suurendamine on võimalik söötmise sellise intensiivsuse korral, kui loomade (pull-kastraatide) kehakaal ületab boniteerimisjuhendi järgi eliitrekordklassi näitajaid $10-$ $15 \%$ võrra.

Iga kilogrammi liha ja rasva, teisiti öeldes - iga 1000 kilokalori tootmine lihana ja rasvana on rikkaliku söötmise korral ökonoomsem (toodanguühiku kohta kulub söötasid kuni 2 korda vähem). Toodanguühiku omahind tuleb odlavam ka siis, kui söötmiseks kasutatavad ratsioonid sisaldavad mitmesuguseid söötasid optimaalsel hulgal ja optimaalses vahekorras vastavalt noorveise vanusele ning arenemisastmele ja kui loomad saadetakse lihakombinaatidesse umbes 1 kuni 1,5 aasta vanuselt.

Kõnesoleva tõu piimalehmad kasutavad sööta tunduvalt efektiivsemalt piima tootmiseks kui noorveised liha ja rasva deponeerimiseks. Arvestades 
konkreetseid võimalusi (eriti söödabaasi olukorda), on ratsionaalne karja remondiks mittevajalikud ja tõuloomadena müügiks mitte arvesse tulevad noorveised suunata lihakombinaatidesse varases nooruses, kuid heas toitumusseisundis. Liha ja rasva tootmiseks remontnoorkarja ülejäägi arvel on otstarbekas kasutada rohkesti mahlakat ja haljassööta, piimaperioodil aga täispiim võimalikult suuremas ulatuses asendada lõssiga.

Eesti NSV Teaduste Akadeemia Loomakasvatuse ja Veterinaaria Instituut
Saabus toimetusse 15. VII 1955

\section{MEAT QUALITIES OF ESTONIAN RED BREED BULL-CALVES AND STEERS, DEVELOPMENT OF TISSUE AND ORGANS UNDER DIFFERENT FEEDING CONDITIONS}

\section{P. ARANDI}

Summary

In order to investigate the beef qualities, the growth of the tissues and of the organs of the young cattle of the Estonian Red Breed, 42 animals grown in differing feeding conditions (in 5 experimental groups) were slaughtered at various ages: immediately after birth, at $3,6,12$ and 18 months old.

In intensively fed groups of 6 months old castrated bulls the carcass weight reaches up to $110 \mathrm{~kg}$, at 12 and 18 months old 217 and $257 \mathrm{~kg}$ respectively, which constitutes up $60-64 \%$ of the live weight. The amount of fat of the inner organs constitutes at 6 months up to $3 \%$, at 12 and 18 months $7-8 \%$ respectively. The fat content of the carcass at 6 months amounts to $3.5 \%$, at 12 and 18 months $12.7-13.6 \%$. The caloric value of a kilogram of beef at intensive feeding varies within the limits of 2500 $2800 \mathrm{kcal}$. Thus the beef and fiat production of the investigated young cattle reaches the level which is characteristic of combined breeds and even of beef clattle. With Estonian Red Cattle fat is deposited (besides the fat of the inner organs) at the surface of the carcass and between the single muscles in larger or smaller streaks and is not divided in the muscles between the muscle fibres; as a result of this, in spite of intensive feeding, the meat does not possess «marble» structure, which is characteristic of the beef breeds.

At moderate, and especially at low plane feeding in the groups grown, the carcass weight land the fat content in the carcass was up to $50 \%$ and over that in the intensively fed groups (data for 6 and 12 months old animals). At moderate feeding the part of the carcass fit for human food increases comparatively less, while the part of the skeleton and the tendons makes up 23-30\%; at rational feeding, however, the respective indexes do not exceed $18-19 \%$ (data for 12 and 18 months old animals).

The most intensive growth of the skeleton, the muscles and the inner organs takes place from the birth to the lage of 6 months. The formation of adipose tissues during that period is moderate even at abundant feeding. In conditions of abundant feeding the rate of the deposition of fat beginning with the second half of the first year of life increases tenfold or even more, 
At moderate feeding the speed of growth of the skeleton and of the important inner organs decreases at a smaller rate than the development of the muscles and the formation of adipose tissue; both the skeleton and inner organs and also the muscles reach their maximum development in animals in good feeding condition.

The highest possible increase of carcass weight, of meat and fat is obtained at such an intensity of feeding at which the body weight of the animals (castrated bulls) surpasses by $10-15 \%$ the indexes of the choice record class given in the improvement instructions.

Proceeding from an economic point of view, the production of each kilogram of meat or fat or of each $1000 \mathrm{kcal}$ in the form of meat and fat is more economical at abundant feeding (the amount of fodder required per unit of production is nearly twice less). The working cost of a unit production is cheaper even when the food-rations contain different kinds of food-stuffs in optimum quantities and in optimum proportions according to the age and development of the young cattle, and when the animals are sent to the slaughter-houses at an age of about 1 to 1.5 years.

The milk-cows of the breed in question use fodder considerably more effectively for producing milk than the young cattle do for depositing meat and fat (the calculations having been made on the basis of the caloric contents of the necessary fodder and of the milk and meat production).

Taking into consideration the potentialities (mainly conditions of the feeding basis), it is economically more rational to direct the young cattle not needed for restocking the herds. and not suitable for breeding to the slaughter-houses in their early youth, but in good feeding condition. In making use of the remainder from the restocking of young cattle for the purpose of producing meat and fat, it is rational to employ in greater quantities roots and green fodder, at the milking period, moreover, to substitute as much as possible skim milk for whole milk.

Academy of Sciences of the Estonian SSR,

Institute of Stockbreeding and Veterinary

Received

July 15,1955 